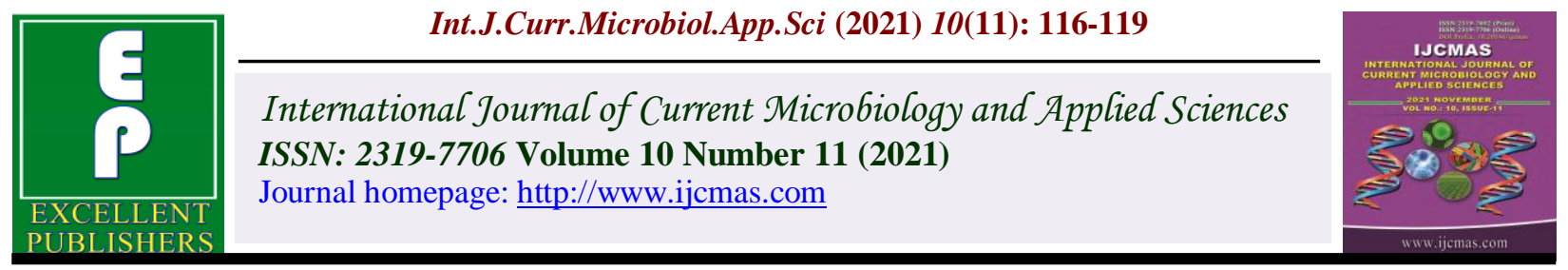

\title{
A Study on Bacterial Etiology of Cholecystitis due to Gallstones and their Antimicrobial Susceptibility Pattern in A Tertiary Care Hospital
}

\author{
B. Gomathi Manju*, N. Rathna Priya and G. Jayalakshmi \\ Department of Microbiology, Institute of Microbiology Madras Medical College, Chennai, \\ Tamil Nadu, India \\ *Corresponding author
}

\begin{tabular}{|c|}
\hline Keywords \\
\hline $\begin{array}{l}\text { Cholelithiasis, Gall } \\
\text { bladder, Sickle cell } \\
\text { disease, Cholesterol }\end{array}$ \\
\hline Article Info \\
\hline $\begin{array}{l}\text { Received: } \\
\text { 05 October } 2021 \\
\text { Accepted: } \\
30 \text { October } 2021 \\
\text { Available Online: } \\
10 \text { November } 2021\end{array}$ \\
\hline
\end{tabular}

Cholelithiasis is a very common condition affecting the Gallbladder. Gallstones are present in $10-15 \%$ of the adult population. Females are three times more likely to develop Gallstones than male. Gall stones are classified into cholesterol and pigment stone. About $80 \%$ of them are cholesterol stone and $15-20 \%$ pigment stone. Obstruction and infections are the common complications of Cholelithiasis. Approximately 1-2\% of the patients become symptomatic and warrants cholecystectomy (1). With this background we conducted a cross sectional study in the Institute of Microbiology, MMC \& RGGGH, for 72 consecutive patients who underwent cholecystectomy. The most common age group affected 41-60 yrs. The most common symptoms are abdominal pain, dyspepsia and Jaundice. In this study Gallstones are collected after surgery, processed and Antibiogram pattern also studied as per standard guidelines. Out of 72 samples studied 35 (48.6\%) are culture positive. Escherichia coli is the predominant organism isolated followed by Klebsiella pneumonia(52). Most of the isolates were sensitive to commonly used antibiotics for Gram Negative bacilli.

\section{Introduction}

Cholelithiasis is a very common condition. Gall bladder is a storage reservoir that allows bile acids to be delivered in high concentration and in a controlled manner to the duodenum for the solublization of dietary lipids. Gallstones are present in $10-15 \%$ of the adult population. Approximately $1-2 \%$ of the patients became symptomatic and warrants cholecystectomy. Nearly 60000 cholecystectomies are performed yearly in the United states for Gallstone related disease. Factors predisposing for the development of Gallstones are Age, Gender, Diet, Pregnancy Crohn's Disese. Hereditary spherocytosis, Sickle cell disease \& Thalassemia. Females are three times more likely to develop 
Gallstones than male. Gall stones are classified into Cholesterol, Pigment \& mixed stones. The major predisposing factor for bacterial infection of the biliary tractis obstruction of biliary system.

\section{Materials and Methods}

We conducted a Cross sectional study, conducted in the Institute of Microbiology and Department of Gastroenterology, Rajiv Gandhi Govt general hospital, Chennai. A total of 72 consequetive patients with cholecystitis, who were posted for cholecystectomy are included. Under strict aseptic condition samples were collected from the patients and transported to laboratory and processing was done. The Gallstones were washed with sterile saline and surface decontamination was done by $70 \%$ ethylalcohol for 10 minutes. Then the Gallstones are powdered and inoculated under aseptic precaution in $15 \mathrm{ml}$ of BHI brot and incubated at $37 \mathrm{c}$ for 48 hours. Plating ws done in Mac Conkey agar and nutrient agar \& Blood agar plates \& incubated at 37 c for 24 hours. As per guidelines Gram Negative \& Gram positive organisms are processed and Antibiotic susceptibility pattern was identified.

\section{Results and Discussion}

Totally 72 patients were included in the study. $62.5 \%$ were females and $37.5 \%$ were males. The most common age group observed is 41-60years and the mean age was 40.5 years. Females outnumbered male in the ratio of 1:06. The most common symptoms observed were abdominal pain and dyspepsia $48.61 \%$ (35) patients were culture positive and $52.39 \%$ were negative. Majority of the cases strains culture positivity age category > 60 years. culture isolates from the culture of both the Common bile duct stone and common bile duct bile was one and the same in all the cases. Most common bacteria isolated was Escherichia coli followed by Klebsiella pneumoniae. Enterococcus faecalis was the only Gram positive organism isolated.

In the present study, majority of the patients with Cholelithiasis were suffering from Chronic cholecystitis which constitute about $62.5 \%$ (35).9 patients showed elevated serum bilirubin and serum alkaline phosphatase which is a useful predictor of choledocholithiasis. Elevation of serum bilirubin, aspirate aminotransferase or alkaline phosphatase are also independent positive to diagnose choledocholithiasis.(54) Laparascopic cholecystectomy was frequently performed in our hospital as it has smaller incision, lesser duration of hospital stay and lesser post post operative wound infection.(46)

Black pigment stones predominated $80.54 \%$ in females than in males $19.43 \%$.The predisposing factors for the formation of black pigment stone include chronic hemolytic state like sickle cell disease, Hereditary spherocytosis, But in our study none of the patient had haemolytic disorders, which concludes that it may be dur to genetic determinant and recurrent biliary tract infection which influence the formation of black pigment stone.(Jayanthi et al.,).

To conclude cholelithiasis is commonly found among the population in the age group $40-60$ years and with increasing age the risk factor for formation of Gall stone increases. Women are more commonly affected than men due to hormonal factors. Fatty, Fertile female of forty are at risk of developing Gall stone formation. In the present study Chronic cholecystitis is more common than Acute cholecystitis due to Gallstones. Diagnosis of Gall stones and its completion is made easier nowadays by non invasive modality like Ultrasonagram. Laparoscopic cholecystectomy is the treatment of choice for cholelithiasis. 
Table.1 Analysis of culture positivity in bile in various types of Gallstones

\begin{tabular}{|c|c|c|c|}
\hline Type of Stone & Number of bile samples & $\begin{array}{c}\text { No of culture positivity } \\
\text { in bile }\end{array}$ & Percentage \\
\hline Cholesterol & 7 & --- & - \\
\hline Pigment & 57 & 30 & $52.17 \%$ \\
\hline Mixed & 8 & 5 & $62.5 \%$ \\
\hline
\end{tabular}

Table. 2 Correlation of culture positivity with the clinical condition

\begin{tabular}{|c|c|c|c|c|c|}
\hline \multirow{2}{*}{} & \multicolumn{5}{|c|}{ Culture Positiviy from clinical samples } \\
\cline { 2 - 6 } & $\begin{array}{c}\text { Gall bladder } \\
\text { stone }\end{array}$ & $\begin{array}{c}\text { CBD } \\
\text { stone }\end{array}$ & Bile & $\begin{array}{c}\text { GB stone } \\
+ \text { Bile }\end{array}$ & $\begin{array}{c}\text { CBD stone } \\
+ \text { Bile }\end{array}$ \\
\hline Acute Cholecystitis & ---- & ---- & $6(40 \%)$ & --- & --- \\
\hline Chronic Cholecystitis & --- & --- & $21(46.6 \%)$ & --- & --- \\
\hline Choledocholithiasis & --- & --- & --- & --- & $8(66.66 \%)$ \\
\hline
\end{tabular}

Table.3 Antimicrobial susceptibility pattern of Gram Negative \& Gram Positive Organism

\begin{tabular}{|c|c|c|c|c|c|c|c|c|c|c|}
\hline \multirow[t]{2}{*}{ Antibiotic } & \multicolumn{2}{|c|}{$\begin{array}{c}\text { Escherichia } \\
\text { coli }\end{array}$} & \multicolumn{2}{|c|}{$\begin{array}{c}\text { Klebsiella } \\
\text { pneumoniae }\end{array}$} & \multicolumn{2}{|c|}{$\begin{array}{l}\text { Klebsiella } \\
\text { oxytoca }\end{array}$} & \multicolumn{2}{|c|}{$\begin{array}{l}\text { Citrobacter } \\
\text { freundii }\end{array}$} & \multicolumn{2}{|c|}{$\begin{array}{c}\text { Pseudomonas } \\
\text { aeruginosa }\end{array}$} \\
\hline & No & $\%$ & No & $\%$ & No & $\%$ & No & $\%$ & No & $\%$ \\
\hline Amikacin & 16 & 94.11 & 7 & 87.5 & 4 & 100 & 3 & 100 & 2 & 100 \\
\hline Gentamicin & 15 & 88.23 & 6 & 75 & 3 & 75 & 3 & 100 & 2 & 100 \\
\hline Ciprofloxacin & 14 & 82.35 & 7 & 87.5 & 3 & 75 & 3 & 100 & 2 & 100 \\
\hline Ofloxacin & 15 & 88.23 & 7 & 87.5 & 3 & 75 & 3 & 100 & 2 & 100 \\
\hline $\begin{array}{l}\text { Cefotaxime/ } \\
\text { Ceftazidime }\end{array}$ & 17 & 100 & 8 & 100 & 4 & 100 & 3 & 100 & 2 & 100 \\
\hline $\begin{array}{l}\text { Piperaciliin - } \\
\text { tazobactum }\end{array}$ & 17 & 100 & 8 & 100 & 4 & 100 & 3 & 100 & 2 & 100 \\
\hline
\end{tabular}

Table.4

\begin{tabular}{|c|c|c|c|c|c|c|c|c|c|c|c|c|c|c|}
\hline & \multicolumn{2}{|c|}{ Ampicillin } & \multicolumn{2}{|c|}{$\begin{array}{l}\text { Erythro- } \\
\text { mycin }\end{array}$} & \multicolumn{2}{|c|}{$\begin{array}{c}\text { Cipro- } \\
\text { floxacin }\end{array}$} & \multicolumn{2}{|c|}{$\begin{array}{l}\text { Tetra- } \\
\text { cycline }\end{array}$} & \multicolumn{2}{|c|}{$\begin{array}{l}\text { High level } \\
\text { Gentanmicin }\end{array}$} & \multicolumn{2}{|c|}{$\begin{array}{l}\text { Vanco- } \\
\text { mycin }\end{array}$} & \multicolumn{2}{|c|}{$\begin{array}{l}\text { Chloram- } \\
\text { phenicol }\end{array}$} \\
\hline & No & $\%$ & No & $\%$ & No & $\%$ & No & $\%$ & No & $\%$ & No & $\%$ & No & $\%$ \\
\hline $\begin{array}{l}\text { Enterococcus } \\
\text { faecalis }(n=4)\end{array}$ & 3 & 75 & 3 & 75 & 4 & 100 & 4 & 100 & 4 & 100 & 4 & 100 & 4 & 100 \\
\hline
\end{tabular}

Culture of bile is very much useful than Gallstones in detecting the etiology of Cholecystitis.

Brown pigment stones showed high culture positivity. Escherichia coli was the most common organism isolated due to the Glucoronidase enzymatic activity which helps in the formation of calcium bilirubinate stones. The present study implies the 
importance of obtaining bile culture at the time of cholecystectomy, so that appropriate antibiotics can be administered in the event of positive bile culture to prevent serious complications like Gram Negative Septicemia.

\section{References}

1.Bailey and Love -Short practice of surgery. 2.Blumgart's Surgery of liver, Biliary tract and Pancreas 5th edition.

3.Sternberg's Diagnostic surgical pathology 5 th edition.

4.Ananth K, Kapur B M L. Chronic cholecystitis and biliary infection. Ind J Surg 1983.

5.Al Harbi M, Osoba A O, Mowallid A, Tract microflora in Saudi patients with cholelithiasis. Trop Med Int Health 2001; 6: 570-574.

6.Ballal M. Bacteriological spectrum of cholecystitis and its antibiogram. Indian J Med Microbiol 2001; 19: 212 -4 .

7.Shrestha R1 Gyawali P1Poudel B1, Sigdel M Khanal M2 Prevalence of different types of gallstone in the patients with cholelithiasis at Kathmandu Medical
College, Nepal (2009), 7 (28) 477-478

8.Tandon R K. Prevalence and type of biliary stones in India. World J Gastroentero,2000;6(Suppl 3):45 (pigments ones predominant in south india)

9.Festi D, Barbara L, Sama C, Banterle C, Taroni F, Rusticali A G, et al., Clinical manifestations of gallstone disease: evidence from the multicentre Italian study on cholelithiasis (MICOL). Hepatology 2004; 30(4): 839-46

10.Muller M F, Stehling M K, Wegmann A. Radilolgic and ultrasound detection of gallstones. Ther Umsch 2006 Aug; 50(8): 547-52.

11.Csendes A, Becerra M, Burdiles P, Demian I, Bancalari $\mathrm{K}$, Csendes $\mathrm{P}$ Bacteriologic studies of bile from the gallbladder in patients with carcinoma of the gallbladder, common bile duct stones and no gallstone disease. Eur $\mathrm{j}$ surg1994 jun160(6-7) ;363-7.

12.Pushpalatha H., Rudresh M. Shooorashetty Bacteriological profile of Cholecystitis and their implication in causing postoperative wound infections. Arch Int Surg $2012 ; 2: 79-82$.

\section{How to cite this article:}

Gomathi Manju, B., N. Rathna Priya and Jayalakshmi, G. 2021. A Study on Bacterial Etiology of Cholecystitis due to Gallstones and their Antimicrobial Susceptibility Pattern in A Tertiary Care Hospital. Int.J.Curr.Microbiol.App.Sci. 10(11): 116-119. doi: https://doi.org/10.20546/ijcmas.2021.1011.015 